\title{
Recommendations for the user-specific enhancement of flood maps
}

\author{
V. Meyer ${ }^{1}$, C. Kuhlicke ${ }^{1}$, J. Luther ${ }^{1}$, S. Fuchs ${ }^{2}$, S. Priest ${ }^{3}$, W. Dorner ${ }^{4}$, K. Serrhini ${ }^{5}$, J. Pardoe ${ }^{3}$, S. McCarthy ${ }^{3}$, \\ J. Seidel ${ }^{4}$, G. Palka ${ }^{5}$, H. Unnerstall ${ }^{6}$, C. Viavattene $^{3}$, and S. Scheuer ${ }^{7}$ \\ ${ }^{1}$ Helmholtz Centre for Environmental Research - UFZ, Leipzig, Germany \\ ${ }^{2}$ Institute of Mountain Risk Engineering, University of Natural Resources and Life Sciences, Vienna, Austria \\ ${ }^{3}$ Flood Hazard Research Centre, Middlesex University, London, UK \\ ${ }^{4}$ University of Applied Sciences Deggendorf, Germany \\ ${ }^{5}$ Université François-Rabelais, École Polytechnique, Département Génie de l'Aménagement, Tours, France \\ ${ }^{6}$ Protestant Academy Hofgeismar (Evangelische Akademie Hofgeismar), Germany \\ ${ }^{7}$ Humboldt University Berlin, Institute of Geography, Germany \\ Correspondence to: V. Meyer (volker.meyer@ufz.de)
}

Received: 23 January 2012 - Revised: 29 March 2012 - Accepted: 19 April 2012 - Published: 24 May 2012

\begin{abstract}
The European Union Floods Directive requires the establishment of flood maps for high risk areas in all European member states by 2013. However, the current practice of flood mapping in Europe still shows some deficits. Firstly, flood maps are frequently seen as an information tool rather than a communication tool. This means that, for example, local stocks of knowledge are not incorporated. Secondly, the contents of flood maps often do not match the requirements of the end-users. Finally, flood maps are often designed and visualised in a way that cannot be easily understood by residents at risk and/or that is not suitable for the respective needs of public authorities in risk and event management. The RISK MAP project examined how end-user participation in the mapping process may be used to overcome these barriers and enhance the communicative power of flood maps, fundamentally increasing their effectiveness.

Based on empirical findings from a participatory approach that incorporated interviews, workshops and eye-tracking tests, conducted in five European case studies, this paper outlines recommendations for user-specific enhancements of flood maps. More specific, recommendations are given with regard to (1) appropriate stakeholder participation processes, which allow incorporating local knowledge and preferences, (2) the improvement of the contents of flood maps by considering user-specific needs and (3) the improvement of the visualisation of risk maps in order to produce user-friendly and understandable risk maps for the user groups concerned. Furthermore, "idealised" maps for different user groups are presented: for strategic planning, emergency management and the public.
\end{abstract}

\section{Introduction}

Flood maps are increasingly regarded as important for mitigating the impacts of natural hazards. According to the $\mathrm{Eu}-$ ropean Commission, they "provide essential information for the public but are also important tools for planning authorities and the insurance industry" (EC, 2004, 2007; cf. also Fuchs et al., 2009). In this way, maps may be used to raise awareness of flooding, by highlighting the communities and individuals at risk, but they also influence planning processes at the local and regional level (Haynes et al., 2007; Hagemeier-Klose and Wagner, 2009). The European Floods Directive (FD) (European Parliament and the Council, 2007) therefore defines the mandatory publication of flood maps as well as flood risk management plans as the most important instruments for enhancing awareness and preparedness of citizens. Member states have to undertake a preliminary flood risk assessment within their river basins, and have to compile flood hazard and risk maps at an appropriate scale in order to serve as a basis for flood risk management plans.

In this context, flood maps are usually divided into hazard maps, showing information on the spatial extent and/or depth of inundation for flood events of different probabilities, and risk maps, showing also the consequences of these events. Flood risk maps as defined by the FD as showing the consequences of specific events with defined probabilities (often also called damage maps), while risk maps in a narrower sense show the consequences for the full range of possible flood events, measured in terms of annual average damage or consequences (European Parliament and the Council, 2007). 
The aim of this paper is to outline recommendations for a user-specific improvement of flood maps, based on the project RISK MAP, funded under the second Era-Net CRUE initiative. The main objective of RISK MAP is to contribute to the enhancement of communities' resilience by improving flood maps. To reach this overall objective, RISK MAP refrains from the assumption that risk maps are purely a oneway means to inform citizens about future risks; used as a basis for two way communication, they are also a means to stimulate public participation between governmental institutions, private companies and associations, alliances, interests groups, and citizens. In this sense, the project pursued a methodological and conceptual research design which centred on the creation of flood maps in different European test sites through a two way, participatory process, where endusers were central. More specifically, three central objectives were comprehensively addressed in RISK MAP:

1. to develop recommendations for an appropriate stakeholder participation process which enables the incorporation of local knowledge and preferences,

2. to improve the contents of flood maps by considering user-specific needs, and

3. to improve the visualisation of risk maps in order to produce user-friendly and understandable risk maps for the user groups concerned.

The aim of the project is to provide recommendations on the above mentioned topics aiming at contributing to recent attempts to provide some reference examples for various authorities and stakeholders in charge of flood map production. While in some of the member countries the methodology of flood mapping is well-established (e.g. Heinimann, 1995, 1998; Hollenstein, 1997; Kienholz and Krummenacher, 1995; Merz, 2006; Merz et al., 2007), in others the situation is quite different. Seidel and Dorner (2011a), for instance, demonstrate in their review of current practices in five European case studies that standards are generally well established with regard to hazard mapping. In contrast, very few examples are available for existing flood damage or even flood risk maps in current practice. Furthermore, the case studies reviewed by Seidel and Dorner (2011a) showed only a few commonalities with regard to the contents and especially the visualisation of flood hazard or - if existing - flood risk maps.

Furthermore, the RISK MAP project utilised the insights and lessons from the EXCIMAP project, providing an overview of existing flood mapping practices in Europe. The resulting "Handbook on good practices for flood mapping in Europe" (EXCIMAP, 2007) included recommendations on the contents of flood maps for different user groups, some hazard and risk modelling techniques and the required data. A further point of reference were the results obtained from the RISKCATCH project (Fuchs et al., 2009), which focussed mainly on visualisation and design aspects of flood risk maps and developed guidelines on these topics, based on the results of eye-tracking tests. This approach was also applied and extended in the RISK MAP project. In addition, we consulted official guidelines developed by the European Commission, such as the "Risk Assessment and Mapping Guidelines for Disaster Management" (European Commission, 2010) as well as the "Recommendations for the establishment of flood hazard and flood risk maps" from the German "Bund/Länderarbeitsgemeinschaft Wasser (LAWA)" (LAWA, 2010). The latter provides detailed guidelines on map contents, data sources, modelling approaches and the visualisation of maps, related to the requirements of the European FD. Merz et al. (2007) as well as De Moel et al. (2009) provide overviews on flood mapping techniques. Applications of flood risk mapping are described for the European (Barredo et al., 2007), national (De Bruijn and Klijn, 2009) or regional scale (Büchele, 2006; Kienberger et al., 2009; Meyer et al., 2009; Ebert et al., 2010).

While the focus of most of these guidelines and publications is on hazard and risk modelling approaches, the focus of this paper is in particular on the end-user's perspective and hence puts a stronger emphasis on meeting their needs by producing such maps in a participatory manner. The necessity to expand the view on flood maps beyond purely technical aspects is highlighted by recent research. In practice maps often fail to attain their potential to fulfil the needs of different users, to raise awareness and provide a clear and understandable source of information for planning. HagemeierKlose and Wagner (2009) and Rowe and Frewer (2000), in particular, found that maps were not very effective in promoting the public to take action to reduce their vulnerability. They found that the public would often respond to a map by disagreeing with the contents, believing them to be inaccurate. Alternatively, they would enter a state of denial to negate the risks (Burningham et al., 2008).

In this respect some of the barriers of risk communication or shortcomings of maps can be identified (Fuchs et al., 2007; Steinführer et al., 2008; Meyer et al., 2009). Firstly, risk communication by flood maps is mostly organised in a one-direction top-down manner. That is, users of the maps, such as the public or emergency managers, are only considered as the receiver of information and are not directly involved in the flood mapping process. This leads to the second problem that the contents of maps are not focussed on the end-users' needs. Flood maps to date have mainly focused on the hazard. If consequences are taken into account, they are mostly expressed in monetary terms, such as risks to buildings and inventories. Other risk criteria, such as social and environmental effects, are often neglected, as well as other user-specific contents (Meyer et al., 2009). Thirdly, flood maps are often designed and visualised by those with a technical knowledge of mapping and/or flooding, and thus the maps present information in a way that cannot be easily understood by laypersons and/or that is not suitable for 
the respective needs of public authorities for risk and flood emergency management (Cronin, 2004; Fuchs et al., 2007; Holub and Fuchs, 2009). Burningham et al. (2008) highlight particular problems in understanding the language of a flood map. Their research emphasised that people "at risk" experienced difficulties in understanding technical language, such as return periods expressed as probabilities (cf. Bell and Tobin, 2007). The RISK MAP project examined how end-user participation in the mapping process may be used to overcome these barriers and enhance the communicative power of flood maps.

Against this background, this paper aims to summarize the main recommendations from the RISK MAP project on stakeholder participation processes (Sect. 4), on the content of maps (Sect. 5) as well as visualisation of flood maps (Sect. 6). However, before providing a more detailed discussion, Sect. 2 outlines the conceptual approach and the overall methodological approach taken by the project. Furthermore, the different map user groups are briefly introduced in Sect. 3. In the final section remaining issues are discussed.

\section{Conceptual approach, empirical basis and methodological design of the RISK MAP project}

The findings and recommendations are based on research undertaken in five different European case studies conducted as part of RISK MAP project: two small Austrian torrent catchments; the Lower Thames River area in England; a section of the Vereinigte Mulde River in the Federal State of Saxony, Germany; the Rivers Vils and Rott in the Federal State of Bavaria, Germany; and the City of Tours at the Loire River in France. The participatory elements of each of the case studies are specified in Table 1 and were organised along three working phases:

i. At first, in each of the case studies the current practices of flood mapping (cf. Seidel and Dorner, 2011) and the respective legal framework for flood mapping (cf. Unnerstall, 2010) were analysed under special consideration of participation activities. Interviews were carried out with stakeholders in order to identify shortcomings of existing maps and the specific needs of different stakeholder groups (see Table 1).

ii. During the second phase, rules for the inclusion of stakeholders were developed (cf. Priest et al., 2011a) (see also Sect. 4). In each case study at least two stakeholder workshops were carried out (see Table 1). During the first workshops participants identified the limitations of existing flood maps and discussed potential improvements with regard to map contents and visualisation. Based on this, new flood maps were compiled considering improved visualisation and contents. Four maps from each case study were tested by selected stakeholders from the different regions with regard to their comprehensibility by means of eye-tracking tests (cf. Serrhini and Palka, 2011), applying and extending the approach developed in the RISKCATCH project and aiming to verify and expand on the initial results (Fuchs et al., 2009). In comparison to RISKCATCH, first, the sample size was increased, second, the focus was very much more on the map reading behaviour of the different user groups and, third, a cognitive survey was added. Figure 1 shows, for example, one of four test maps developed in the case study Saxony. During the eye-tracking tests, each of the 20 maps was projected for $15 \mathrm{~s}$ in order to see which constitutive elements of the map attract the volunteers' eye during the first few moments of the projection. The record gives the number, duration and sequence of eye fixations. The analysis of the average number and duration of fixations can define how easy or hard it is for every individual to read a map. Using an additional cognitive survey, the maps were subsequently evaluated by the test persons. The survey includes an evaluation of ten maps (two per test site). Each individual was asked to evaluate five criteria for each map presented: complexity, density of information, aesthetic aspect, innovation, and usefulness with respect to risk management tasks. The main aim of the survey was to identify correlations between the different criteria. Finally, the last part of the survey addressed the preferences of individual groups of potential endusers with respect to scale, legend, hazard and impact, number of topics presented and map type. During the second workshops the results of these eye-tracking tests were discussed with stakeholders, and new maps, based on the results from the first workshops and from the eyetracking tests, were presented and discussed. Additionally, for the Saxon case study, a multicriteria risk mapping tool (FloodCalc, see Scheuer et al., 2011) was used to include the stakeholders' preferences in the updated flood maps.

iii. During the final project phase, the results from the second workshops were used for a second update of maps. Figure 2 later in this paper shows an example for a final map from the case study Saxony, illustrating the updates made to Fig. 1 after the eye-tracking tests and the second workshop. A more detailed description of the different case studies results, methodological backgrounds and findings can be found in Meyer et al. (2011), Priest et al. (2011a, b), Seidel and Dorner (2011a, b), Scheuer et al. (2011), Serrhini and Palka (2011) and Unnerstall $(2010,2011)$. Furthermore, the different case study results were used to synthesise some common recommendations for improved flood mapping, which will be outlined in the following sections. 
Table 1. Overview of the participatory process in RISK MAP.

\begin{tabular}{|c|c|c|c|}
\hline Number of interviews & Workshop I & Workshop II & Eye-tracking tests \\
\hline \multicolumn{4}{|c|}{ England: (Local residents experienced and at risk from flooding) } \\
\hline Not specified & $\begin{array}{l}\text { Exploratory workshops A and B } \\
\text { 13/14 participants } \\
\text { Aim/Activities: } \\
\text { - Explore participatory ap- } \\
\text { proaches to using flood maps } \\
\text { for engaging the public } \\
\text { Discussing and exploring lo- } \\
\text { cal knowledge, which could } \\
\text { be used to improve the flood } \\
\text { maps } \\
\text { - Identifying public users of } \\
\text { the flood maps and observing } \\
\text { how users interact with the in- } \\
\text { formation on flooding } \\
\text { - Investigating public opinions } \\
\text { on the current Environment } \\
\text { Agency maps } \\
\text { - Identifying recommendations } \\
\text { for improvement of the maps } \\
\text { in terms of visualisation and } \\
\text { content. } \\
\text { Blank map and puzzle exercises, } \\
\text { commenting on existing maps and } \\
\text { post workshop questionnaire }\end{array}$ & $\begin{array}{l}\text { Findings Workshop } \\
9 \text { participants } \\
\text { Aim/Activities: } \\
\text { Usefulness of participatory ap- } \\
\text { proaches, inclusion of local knowl- } \\
\text { edge in maps, use of information } \\
\text { provided in maps, opinions about } \\
\text { existing maps, improving visualisa- } \\
\text { tion and content } \\
\text { - Provide the opportunity to } \\
\text { present the maps that were } \\
\text { tested by EGS as well as up- } \\
\text { dated maps based on its out- } \\
\text { comes. } \\
\text { - Verify and clarify findings } \\
\text { from the initial workshops } \\
\text { in terms of visualisation and } \\
\text { content preferences } \\
\text { - Explore further ideas of en- } \\
\text { gaging the public in a dialog } \\
\text { process about the flood map as } \\
\text { well as verifying ideas on par- } \\
\text { ticipation generated from the } \\
\text { exploratory workshop. } \\
\text { post-workshop questionnaire }\end{array}$ & $\begin{array}{l}9 \text { participants } \\
\text { Aim/Activities: } \\
\text { To explore how the sample maps } \\
\text { are perceived, understood and eval- } \\
\text { uated by different user groups from } \\
\text { different case studies (valid for all } \\
\text { other case studies) }\end{array}$ \\
\hline
\end{tabular}

Saxony: Professionals from a range of agencies and organisations, additional on MCA risk assessment and on the development of a knowledge database/ontology for the inclusion of local knowledge

9 interviews before the 1 st
workshop
6 interviews before the 2 nd
workshop
Aim:
- To explore current prac-
tices of flood mapping in
the case study and the
central issues to be fo-
cused upon during the
workshops

12 participants from 5 institutions Aim/Activities:

- See above

Blank map and puzzle exercises, post-workshop questionnaire
6 participants from 4 institutions Aim/Activities:

- See above

Commenting, post-workshop questionnaire

Bavaria: Professionals from emergency management

\begin{tabular}{|c|c|c|}
\hline 8 interviewed institutions & Participants from 6 institutions & Participants from 6 institutions \\
\hline Aim: & Aim/Activities: & Aim/Activities: \\
\hline $\begin{array}{l}\text { - To identify the specific } \\
\text { needs and requirements of } \\
\text { specific end-user groups } \\
\text { in the project. The in- } \\
\text { terview participants were } \\
\text { asked the same questions } \\
\text { as the participants of the } \\
\text { workshops. }\end{array}$ & $\begin{array}{l}\text { - To identify the specific needs } \\
\text { and requirements of specific } \\
\text { end-user groups in the project } \\
\text { moderated discussion (questions } \\
\text { on operational experiences, use of } \\
\text { maps, information needed in the } \\
\text { maps) }\end{array}$ & $\begin{array}{l}\text { - To confront the different user } \\
\text { groups with the flood hazard } \\
\text { maps and flood risk maps, im- } \\
\text { proved and produced during } \\
\text { the first phase of the project } \\
\text { and tests via eye-tracking, and } \\
\text { to foster discussions of pos- } \\
\text { sible adjustments of the cur- } \\
\text { rent suggestion for implemen- } \\
\text { tation }\end{array}$ \\
\hline
\end{tabular}

8 participants from 3 institutions including laypersons and scientists 
Table 1. Continued.

\begin{tabular}{|c|c|c|c|}
\hline \multicolumn{4}{|c|}{ Austria: Professionals from the Austrian Torrent and Avalanche Control Service } \\
\hline $\begin{array}{l}1 \text { interview with a representative of } \\
\text { the Lower Austrian Centre for Civil } \\
\text { Protection as an official emergency } \\
\text { management body within the } \\
\text { Federal State of Austria } \\
\text { Aim: } \\
\text { - To explore the map content } \\
\text { of risk maps with respect } \\
\text { to event management (emer- } \\
\text { gency planning and evacua- } \\
\text { tion) }\end{array}$ & $\begin{array}{l}18 \text { representatives of the Austrian } \\
\text { Torrent and Avalanche Control Ser- } \\
\text { vice } \\
\text { Aim/Activities: } \\
\text { - To include specific needs of a } \\
\text { specific end-user group in the } \\
\quad \text { RISK MAP project (emphasis } \\
\text { on content and visualisation) } \\
\text { Round-table discussion and presen- } \\
\text { tations }\end{array}$ & $\begin{array}{l}8 \text { representatives of the Task Force } \\
\text { of the Implementation of the FD in } \\
\text { Austria under the umbrella of the } \\
\text { Umweltbundesamt GmbH } \\
\text { in Vienna } \\
\text { Aim/Activities: } \\
\text { - To confront the working } \\
\text { group responsible for the } \\
\text { implementation of the Euro- } \\
\text { pean FD into practice with } \\
\text { the results obtained within } \\
\text { the RISK MAP project, } \\
\text { and to foster discussion } \\
\text { of possible adjustments of } \\
\text { the current suggestion for } \\
\text { implementation } \\
\text { - Present results, compare } \\
\text { preliminary results of RISK } \\
\text { MAP with existing practices } \\
\text { and provide recommendations }\end{array}$ & $\begin{array}{l}9 \text { participants including } \\
\text { researchers }\end{array}$ \\
\hline \multicolumn{4}{|c|}{ France: Professionals from a range of agencies and organisations } \\
\hline $\begin{array}{l}9 \text { interviewed institutions } \\
\text { Aim: } \\
\text { - To explore current practices } \\
\text { of flood mapping in the case } \\
\text { study and the central chal- } \\
\text { lenges and issues to be } \\
\text { focused on more in-depth } \\
\text { during the workshops }\end{array}$ & Not applicable & Not applicable & $\begin{array}{l}10 \text { representatives from } \\
9 \text { institutions }\end{array}$ \\
\hline
\end{tabular}

\section{User groups of flood maps}

A key result emerging from all case studies was that different users or user groups have different needs with regard to flood maps and that these requirements might not necessarily be in accordance or understood by those producing the maps. This confirms Zeisler's (2010) argument that the map creation process should be led by the requirements of the users (see also EXCIMAP, 2007). There is a large variety of users who use a different "language" and pursue different objectives. In the following three major user groups are distinguished (see also classification by the EXCIMAP (2007), which indicates spatial planners as a separate category and furthermore adds the private sector, in particular, the insurance industry, as a fifth group):

\section{Map users from strategic planning:}

The case studies recognised that persons from this group are often from the same agency responsible for the creation of flood maps. However, in other cases end-users are members of regional branches of the agency responsible for flood risk management. Maps are used here as a basis for strategic decisions on flood risk management/flood protection measures. Users in this group are usually experts by profession in using flood maps and they use them regularly in their daily work. Moreover, at least in normal decision processes, there is usually sufficient time to study the maps in detail. Our research showed that map users of this group are able to deal with a high density of information within the maps and that they are able to comprehend technical content, such as exceedance probabilities, annual average damages, etc.

Within this group, another sub-group can be differentiated: spatial planning end-users. This group is usually also involved in contributing to strategic flood risk management, but is often located within a different organisation or department. Planners by profession may be less familiar with flood maps and place slightly different requirements from flood maps.

2. Map users from emergency management:

Emergency or disaster management may be institutionally separated from strategic planning in flood risk 


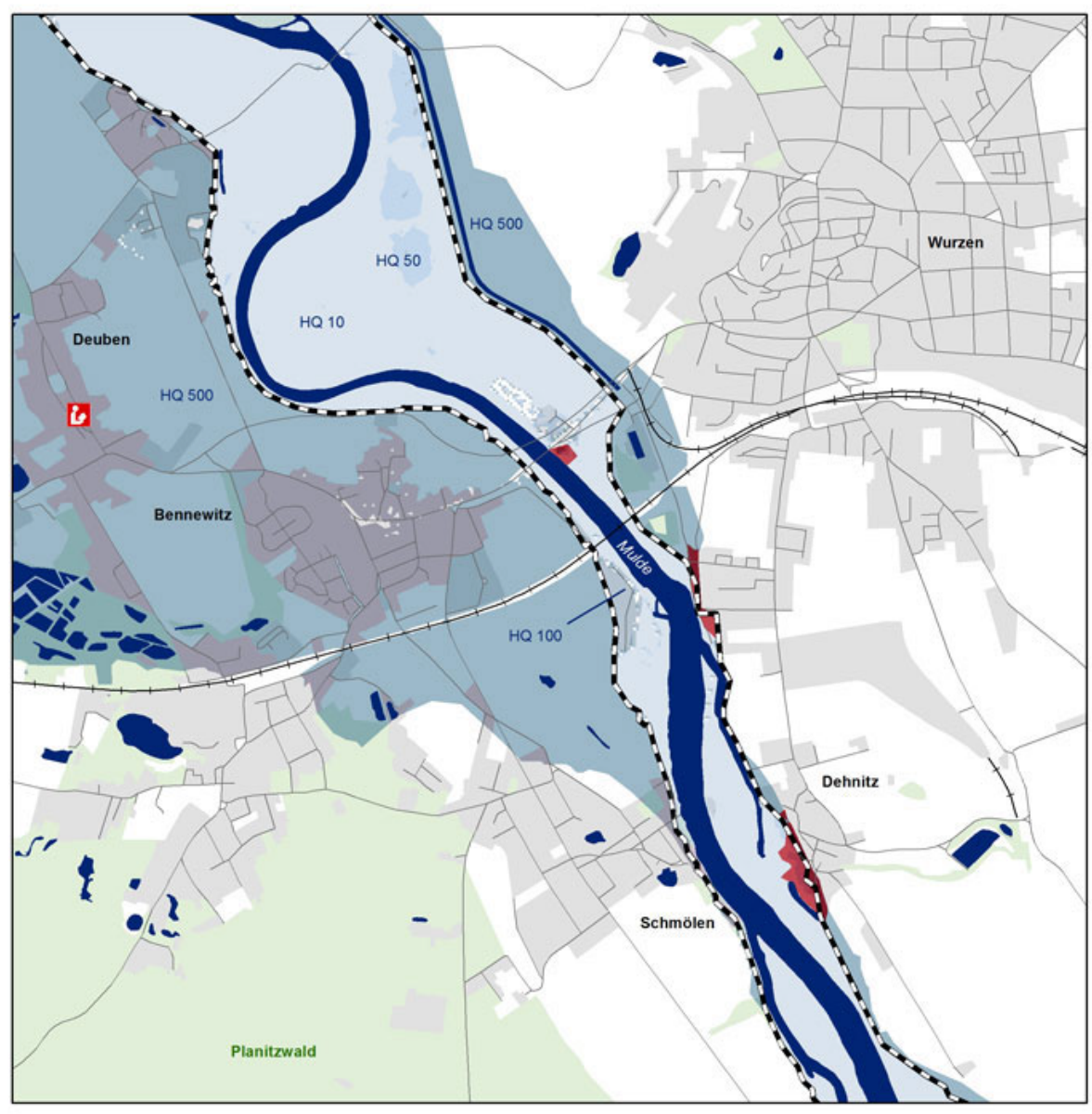

z-Zentrum für Umweltforschung GmbH - UFZ. Design and Cartography: S. SCHEUER, V. MEY
This project is founded within the ERA-NET Crue funding initiative (ERAC-CT-2004-515742)
BENNEWITZ / WURZEN (Ger)

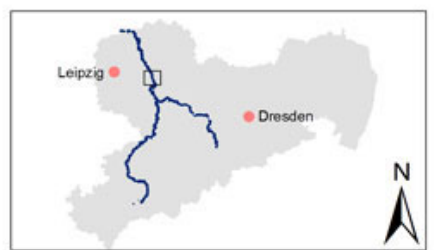

Flood hazard map

Hochwassergefährdungskarte

Cartographie des zones inondables
Flood extent - Hochwasserausdehnung Etendue de la crue

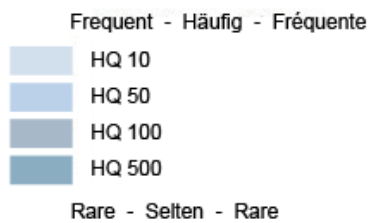

Population at risk - Gefährdete Bevölkerung Population affectée (HQ 500) [//km²]

\section{$0 \ldots 2000$}

$2000 \ldots 4000$

6. Primary school - Gefährdete Grundschule Ecole primaire

-.. Embankment - Deich - Digue

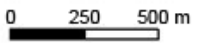

Fig. 1. Example for a test map for the eye-tracking-tests (case study Saxony): map contents include flood extent and population at risk.

management. Responsibilities are, for example, in the local or regional administrations of municipalities or districts, and often also fire brigades or armed forces are involved. The main purpose of flood maps in this field is to provide quick access to information about affected areas in the event of an emergency, such as people to be evacuated, critical infrastructure to be protected or evacuation routes. As flooding (or water) is often not their sole responsibility, users from this group may have less experience and familiarity with flood maps than map users from strategic planning. This poses problems as it may be that this group is less familiar with the scientific concept of risk, i.e. the mapping of annual average consequences, and as such, aggregated information may be less relevant for their day-to-day use of the maps.

\section{Map users from the public:}

Citizens are usually neither directly involved in producing the maps, nor do they deal with them on a professional basis. However, flood maps are often directed towards them with the aim of raising awareness. It can be assumed(and the case studies indicate it) that their use of flood maps is generally infrequent and hence may have less experience with such maps. As such, this group is likely to be unfamiliar with concepts such as exceedance probabilities or annual average damages. On the other hand members of the public are more likely to rely on a detailed contextual knowledge, gained from previous experiences of flooding. They may therefore be able to make valuable contributions to mapping process, providing a different type of knowledge and information to enrich map content and visualisation. Aside from this, there is a further sub-group: the organised public. This group consists of environmental or business interest groups and similar groups, which represent particular interests. 


\section{Recommendations on stakeholder participation processes}

\subsection{Purpose of participation}

The manner in which a participatory flood mapping process should be set up and conducted depends largely on the purpose of the process itself. Defining this purpose is therefore a key issue that should ideally be clarified at the beginning of a participatory process. Based on the argument of Fiorino, we propose to distinguish between a substantive and an instrumental rationale for a participatory risk mapping process (Fiorino, 1989; cf. also Stirling, 2006).

The substantive rationale for adopting a participatory mapping approach aims at increasing the breadth and depth of knowledge that contributes to a decision, as participation allows for the inclusion of tacit or local knowledge that can improve the quality of a map. Many residents have had personal experience of hazardous events and hence have good understanding of issues in their local area. The work of Leone and Lesales (2009), for instance, shows that local knowledge can be incorporated into modelled maps to produce an improved product. This is also supported by the findings of the RISK MAP project. Therefore, one of the key recommendations from the project was that the degree to which the instrumental and substantive rationales are accommodated and the manner of participation undertaken should be tailored to the project objectives.

The instrumental rationale emphasises that a participatory mapping approach may contribute to building trust between actors from the public and administrative sphere and may also contribute to raising people's awareness and motivation for taking actions to mitigate the impacts of hazards. Research shows that participatory mapping approaches as participation in general are able to contribute to increase acceptance and to building trust between actors from the public, administrative and scientific sphere but also may contribute to raising people's awareness and motivation for taking actions to mitigate the impacts of hazards (Stirling, 2006; Höppner et al., 2010).

In this sense, the answer to the question, "What should be achieved by the participatory process?" is decisive as it has implications for the choice of actors to be involved in the process, the intensity of the process as well as the outcomes of the entire process. In the following section we outline some characteristics of a participatory process, following a substantive and an instrumental rationale (see also Table 2).

\subsection{Substantive rationale: participation for improving the content of risk maps}

If a participatory process follows a substantive rationale, it aims to increase the breadth and depth of knowledge contributing to the final product. Examples include attempts to include more contextualised forms of knowledge that cannot simply be reproduced by modelling exercises. This is evidenced by updated models refining flood extents but also by the very nature of flood risk as a dynamic and evolving risk. Flood risk alters over time as landscapes and climates change. In order to improve the data and information available on flood risk, traditional modelling can be supplemented by additional more "informal" sources of knowledge. Capturing this knowledge requires a participatory approach to flood risk mapping.

\subsubsection{Possible participants}

Participants may be both from the professional field of flood risk management (e.g. strategic planners as well as emergency managers) as well as from the public. A decisive criterion, however, for the latter group would be that participants have some kind of contextual knowledge on flood risks. Their expertise might be gained either by formal education and hence testified by some kind of degree and/or professional background or it might be gained by experience and personal observation as an informal process of knowledge acquisition (cf. also Collins and Evans, 2002). This group may therefore contain local residents, who may have knowledge of the local hydrological and hydraulic mechanisms of flooding and expertise about the history of flooding in their neighbourhood.

\subsubsection{Participatory process}

The process would be quite intensive and would comprise a series of meetings. Both representatives from the public and those with a professional background would be treated as equals, implying that they both have an equal right to influence the decision-making process. Such a process aims at creating open and mutual exchange while allowing the identification of different or similar opinions/worldviews/values among and between different actors; it also aims to ensure the participants influence the final decision-making process (cf. Arbter et al., 2007; Kuhlicke and Steinführer, 2010; Kenyon et al., 2001).

\subsection{Instrumental rationale: participation for risk awareness}

On the other side of a participatory spectrum is a process aiming at an instrumental rationale. Here building trust among involved stakeholders as well as raising risk awareness is at the core of the process. Maps are useful tools in raising risk awareness, and workshops offer the opportunity to review, deliberate and discuss the maps in a group situation. In order to raise awareness of flood risk through mapping workshops, the participants should comprise small groups, where those inexperienced and unaware of the risk are able to participate alongside others who have experienced flooding. By working in such mixed groups, participants may interact with each other, allowing those affected by flooding 
Table 2. Recommendations for participatory processes for different aims.

\begin{tabular}{llll}
\hline & $\begin{array}{l}\text { 1. Substantive } \\
\text { (e.g. improving content) }\end{array}$ & $\begin{array}{l}\text { 2. Instrumental - substantive } \\
\text { (e.g. verifying content) }\end{array}$ & $\begin{array}{l}\text { 3. Instrumental } \\
\text { (e.g. raising risk awareness) }\end{array}$ \\
\hline Participants & $\begin{array}{l}\text { Those with "expert" knowledge on } \\
\text { a subject (e.g. strategic planners, } \\
\text { emergency managers and citizens } \\
\text { with expertise by experience) }\end{array}$ & $\begin{array}{l}\text { Open to all stakeholders. Mixed } \\
\text { groups of stakeholders }\end{array}$ & $\begin{array}{l}\text { Individual members of the general } \\
\text { public }\end{array}$ \\
\hline Process & $\begin{array}{l}\text { Series of meetings centred on pro- } \\
\text { duction and verification of maps. }\end{array}$ & $\begin{array}{l}\text { Intensive and iterative engagement, } \\
\text { repeated meetings to report and } \\
\text { check changes }\end{array}$ & $\begin{array}{l}\text { One meeting to raise risk aware- } \\
\text { ness. Two or more meetings to } \\
\text { improve trust and legitimacy. }\end{array}$ \\
\hline Map & Focussed on content but also & $\begin{array}{l}\text { Content selection, verification and } \\
\text { visualisation. }\end{array}$ & $\begin{array}{l}\text { Focussed on intuitive usability for a } \\
\text { broad and general audience }\end{array}$ \\
\hline vutcome & Verification of existing contents. & $\begin{array}{l}\text { Raising awareness, maps } \\
\text { tailored to end-user preferences, } \\
\text { increased trust and development of } \\
\text { co-operation networks. }\end{array}$ & $\begin{array}{l}\text { Raising awareness, tailored maps to } \\
\text { suit end-users, increased trust and } \\
\text { legitimacy. }\end{array}$ \\
& & &
\end{tabular}

in the past to share their experience(s) and the lessons they learned.

\section{Recommendations on the content of flood maps}

One major research question in RISK MAP was to find out which hazard or risk variables are of key significance for end-users and should therefore be displayed in flood maps. As stated previously in Sect. 3, flood maps should to be tailored to the needs of end-users and this is particularly true with flood map content. In this section general recommendations on the contents of flood maps are presented before moving on to the recommendations for the different enduser groups as specified above: strategic planners, emergency planers and the general or potentially affected public. Many recommendations on the contents of flood maps for different user groups have already been provided by the EXCIMAP project (EXCIMAP, 2007). These findings have also been considered within the following recommendations and have been confirmed and enhanced by additional findings from research conducted in the RISK MAP project.

\subsection{General recommendations on the content of flood maps}

The contents that are required in Article 6 of the European FD build a very good basis for communicating risks to the end-users. However, they should not be seen as the final product. As stated in the FD, these contents could be extended by other useful information, such as in particular risk or emergency management information. Our case study results showed that many end-users (from the public, emergency management as well as strategic planning) find it very useful to have information on existing (or planned) defences, evacuation routes and assembly points, etc. already integrated in the maps.

These map contents have up to now not been required by Article 6 of the FD. However, hazard and risk maps should be also part of the flood risk management plans (see Article 7 of the FD). The process of the development of risk management plans can be seen as a possibility to further adjust the contents of the hazard and risk maps according to the specific end-user needs.

\subsection{Recommendations on the content of flood maps for strategic planning}

As specified in Sect. 3, map users in this group are usually very experienced in the work with both hazard and risk maps. Furthermore, at least in normal working situations, they have sufficient time to study maps in detail. Consequently, they are able to deal with a high density of information displayed on the map and complex scientific contents. The key purpose of flood maps for strategic planning is to highlight areas of high risk, and therefore to show where there is a requirement for mitigation efforts. Maps also serve as an intermediate product for economic appraisal of flood risk mitigation measures. For this purpose flood risk needs to be calculated for the situation with and without the planned measure(s) in order to estimate their risk reducing effect. Specific content requirements are (see also Table 3)

- With regard to hazard information especially, detailed information on flood extent and depth for events with different probabilities is required. If available, additional information on flow velocities can also be helpful.

- Consequences should be shown for specific events (damage maps), but also in an aggregated way over the 

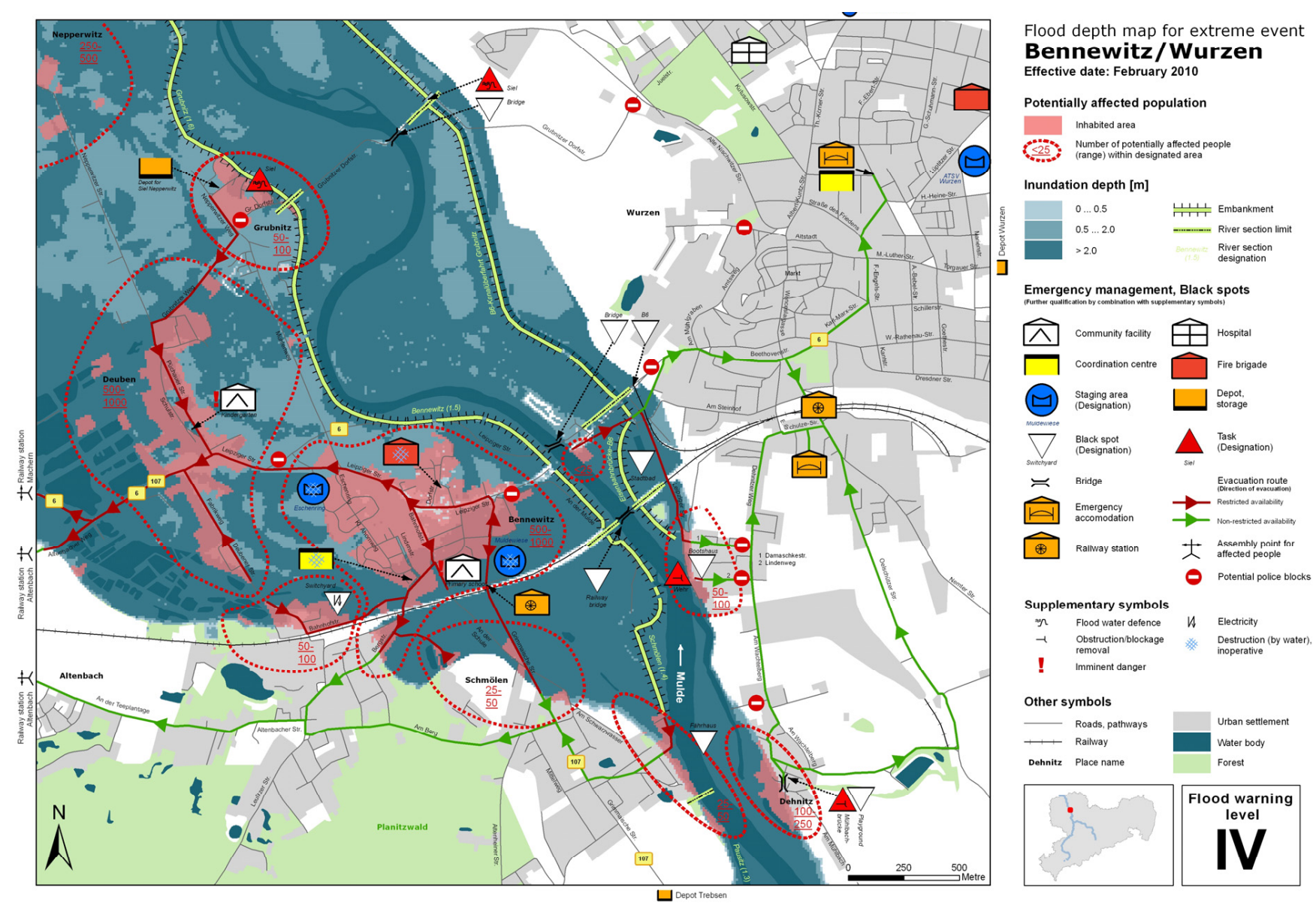

Fig. 2. Example for a map for emergency management (case study Saxony): Map contents include inundation depth and affected population, but also important emergency management information (coordination centre, assembly points, evacuation routes) and critical infrastructure. Map contents and visualisation have been updated (compared to Fig. 1) based on the results of the eye-tracking tests and the second stakeholder workshop.

full range of possible events (risk maps in a narrow sense), i.e. maps showing the annual average damage. The latter is in particular required as a basis for economic appraisals.

- As already required by the European FD, not only information on the economic damages should be shown but also information on social, cultural and environmental risks in order to show a complete picture of possible consequences. This should also include critical infrastructure, such as bridges, power plants, hospitals, etc.

- An aggregation of these different social, economic and environmental risks by means of a multicriteria risk map can be helpful for strategic planning, in order to show overall risk hot spots.

- Maps for strategic planning should also include information on existing flood protection, protected areas and residual risk in these areas.

\subsection{Recommendations on the content of flood maps for emergency management}

The main purpose of flood maps in this field is to enable quick access to information in the event of flooding. This information might include those areas likely to be affected, people to be evacuated, the critical infrastructure to be protected and evacuation routes. According to the findings of the different case studies, content requirements of emergency managers are, in particular, the following(see also Table 3):

- With regard to hazard information, maps for emergency management should include information on the flood extent of events with different probabilities. Information on critical depth and velocities can also be valuable in order to show the accessibility of certain areas. Furthermore, a clear link to alarm stages and critical water levels at gauges upstream needs to be established in order to provide rapid information about which area will be 
Table 3. Map contents required by different end-user groups.

\begin{tabular}{|c|c|c|c|}
\hline & Strategic planners & Emergency planners & General public \\
\hline $\begin{array}{l}\text { Information } \\
\text { density/complexity }\end{array}$ & - High & - High & - Low \\
\hline Hazard & $\begin{array}{l}\text { - Flood extent and depth } \\
\text { (different probabilities) } \\
\text { - Flow velocities were available }\end{array}$ & $\begin{array}{l}\text { - Flood extent and depth } \\
\text { (different probabilities) } \\
\text { - Critical depth and velocities } \\
\text { - Link to alarm stages }\end{array}$ & $\begin{array}{l}\text { - Flood extent and depth (high, } \\
\text { medium, low probability, if } \\
\text { available also for recent or } \\
\text { historical events) } \\
\text { - Link to alarm stages }\end{array}$ \\
\hline Consequences/risk & $\begin{array}{l}\text { - Event specific damage, also } \\
\text { annual average damages (for } \\
\text { economic appraisals) } \\
\text { - Economic, social, cultural } \\
\text { and environmental risks } \\
\text { - critical infrastructure }\end{array}$ & $\begin{array}{l}\text { - Number of people at risk (to } \\
\text { be evacuated) } \\
\text { - Critical infrastructure } \\
\text { (to be protected or evacuated): } \\
\text { hospitals, energy and water } \\
\text { supply, traffic infrastructure }\end{array}$ & $\begin{array}{l}\text { - Buildings (affected) } \\
\text { - Roads (affected) }\end{array}$ \\
\hline $\begin{array}{l}\text { Additional } \\
\text { information }\end{array}$ & $\begin{array}{l}\text { - Existing flood defence, } \\
\text { protected areas, } \\
\text { residual risk }\end{array}$ & $\begin{array}{l}\text { - Emergency management } \\
\text { information: assembly points, } \\
\text { evacuation routes, etc. } \\
\text { - Existing flood defence, poten- } \\
\text { tial weak points, protected areas } \\
\text { - Usability of e.g. evacuation } \\
\text { routes, hospitals }\end{array}$ & $\begin{array}{l}\text { - Most important emergency } \\
\text { management information: shel- } \\
\text { ter, assembly points, evacuation } \\
\text { routes, hospitals }\end{array}$ \\
\hline
\end{tabular}

flooded if the water level rises above certain threshold values.

- Information about existing flood defences is important too, in order to provide information on at which level a failure of defences is possible and which areas would be affected in such a case. Furthermore, potential weak points in the defence line which require special attention or action in case of an event should be included in the maps.

- The information on consequences of flooding, which is particularly important for emergency management, includes the number of people who are at risk from flooding and who would need to be evacuated in case of emergency. Additionally, critical infrastructure (such as hospitals, energy or water supply facilities, waste water treatment facilities, roads and bridges) should also be displayed on the maps.

- Apart from traditional hazard and risk information, information on emergency management itself should also be included in the maps, such as assembly points, evacuation routes, hospitals, coordination centres and gauging stations (see Fig. 2). But these facilities can also be at risk from flooding themselves. Therefore, additional information should be included in the maps, which details the level of flooding these emergency facilities are themselves at risk, for instance, when certain evacuation routes become unusable.

\subsection{Recommendations on the content of flood maps for the public}

Many maps are directed towards the public (e.g. to raise their awareness of flood risk and to provide motivation for flood risk preparation). In contrast to the previously mentioned groups, public users, in most cases, do not use flood maps very frequently and therefore often have different needs and requirements in terms of mapped content. The case studies found that, in general, flood maps for the public should be less complex and should contain the following basic information (see also Table 3):

- Firstly, inundation extent and depth information for different specific events were considered critical by public users and should be presented on flood maps as the most important hazard information. As many citizens are not necessarily familiar with the concept of return periods or exceedance probabilities, such expressions and other technical language should be avoided and rather terms like "small, medium or extreme event" should be adopted. Also the extent and depth of recent or historical events could be shown as it assists users in relating the modelled information to their personal 


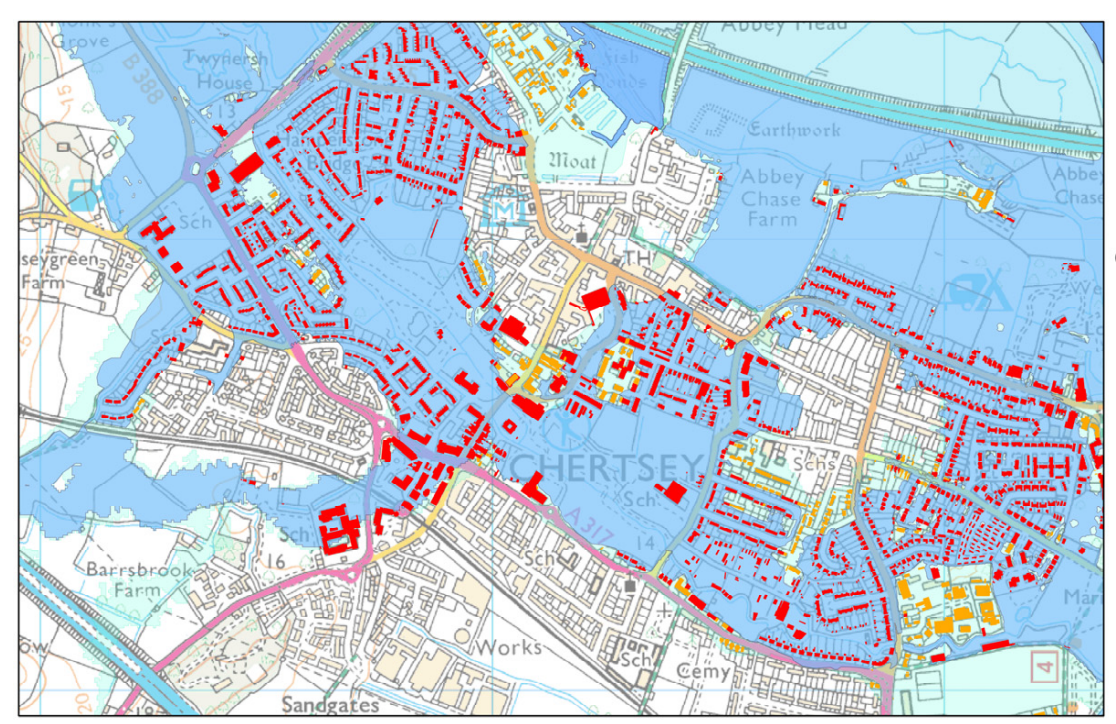

\title{
Chertsey, Surrey, UK
}

\author{
Environment Agency flood map \\ altered based on feedback \\ from public workshops

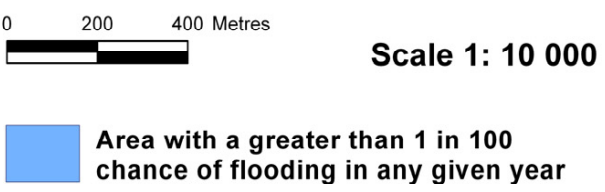

Area with between 1 in 100 and 1 in 1000 chance of flooding in any given year

Properties located within areas with a greater than 1 in 100 chance of flooding in any given year

Propertles located within 1 In 100 and 1 in 1000 year flood risk area

Reproduced by permission of Ordnance Survey on behalf of HMSO. (c) Crown copyright and database right 2010. All rights reserved. Ordnance Survey Licence number 100026380.' All flood extent data is produced with the permission of the Environment Agency. License Reference: Z2644

Fig. 3. Altered Environment Agency flood map for the public (case study England): contents have been refined based upon the preferences of Chertsey workshop participants. Map contents include flood extents for two different return periods and highlights buildings potentially affected. Emergency management information is not included in this example.

experience and creates a better contextualisation of the flood hazard.

- Maps for the public do not need to include information on potential consequences of flooding in terms of damages. However, all buildings and roads in the area should be shown on the map. This helps users to orientate themselves and to identify if their property would be affected in the case of a certain flood event. Therefore, those buildings located within the flood extent and that are likely to be affected during flooding should be highlighted (see for example Fig. 3).

- Selected information on emergency management is useful also for map users of the general public. In particular, information on evacuation routes and assembly points should be included in the maps in order to guide people on how to behave in case of emergency.

\section{Recommendations on the visualisation of flood maps}

In order to communicate the above mentioned contents of maps to the end-users, it is furthermore important that the maps are designed and visualised in a way that can be easily understood by the end-users. Based on findings from RISKCATCH (Fuchs et al., 2009) and additional insights gained from RISK MAP project (Meyer et al., 2011), the following general and user-specific recommendations are suggested (see also Table 4).

\subsection{General recommendations on the visualisation of flood maps}

Some general recommendations on the visualisation of maps were derived by the RISKCATCH project (Fuchs et al., 2009). These recommendations have been further confirmed by this project through widening the sample of eye-tracking participants and in particular through testing the recommendation with a broader range of flood map users:

- Areas at risk should be clearly visually differentiated from areas not at risk. In practice this means that areas or properties at risk should be highlighted using strong colours, while background information, such as properties not at risk, should be kept simple and in pale colours (see e.g. Fig. 4).

- The legend should be sufficiently large, preferably on the right side of the central element of the map, with a limited amount of information. Legend themes in graduated colours (e.g. inundation depth, damage or risk) should not have more than five classes of discretisation, comprised from one range in colour only and arranged in decreasing values.

- A sufficiently large scale is required so that mapped elements are easily and speedily recognisable by users.

Based on the eye-tracking test and cognitive surveys carried out in the RISK MAP project (Serrhini and Palka, 2011), these findings have been extended and further specified, leading to these additional recommendations: 
Table 4. Recommendations for visualisation.

\begin{tabular}{llll}
\hline & Strategic planners & Emergency planners & General public \\
\hline Information density/complexity & - High & $\begin{array}{l}\text { - High, but quick access to in- } \\
\text { formation }\end{array}$ & $\begin{array}{l}\text { - Low, quickly and easily } \\
\text { understandable }\end{array}$ \\
$\begin{array}{llll}\text { Legend } & - \text { Up to 5 classes } & - \text { Not more than } 3 \text { classes } & - \text { Not more than } 3 \text { classes } \\
\begin{array}{l}\text { Hazard and consequences in the } \\
\text { same map? }\end{array} & - \text { Yes } & - \text { Yes } & \text { - Mainly hazard information } \\
\text { Additional map elements } & - \text { Optional } & - \text { Symbols (commonly used) } & - \text { Symbols (self-explanatory) } \\
& & - \text { Text } & - \text { Text }\end{array}$ \\
\hline
\end{tabular}
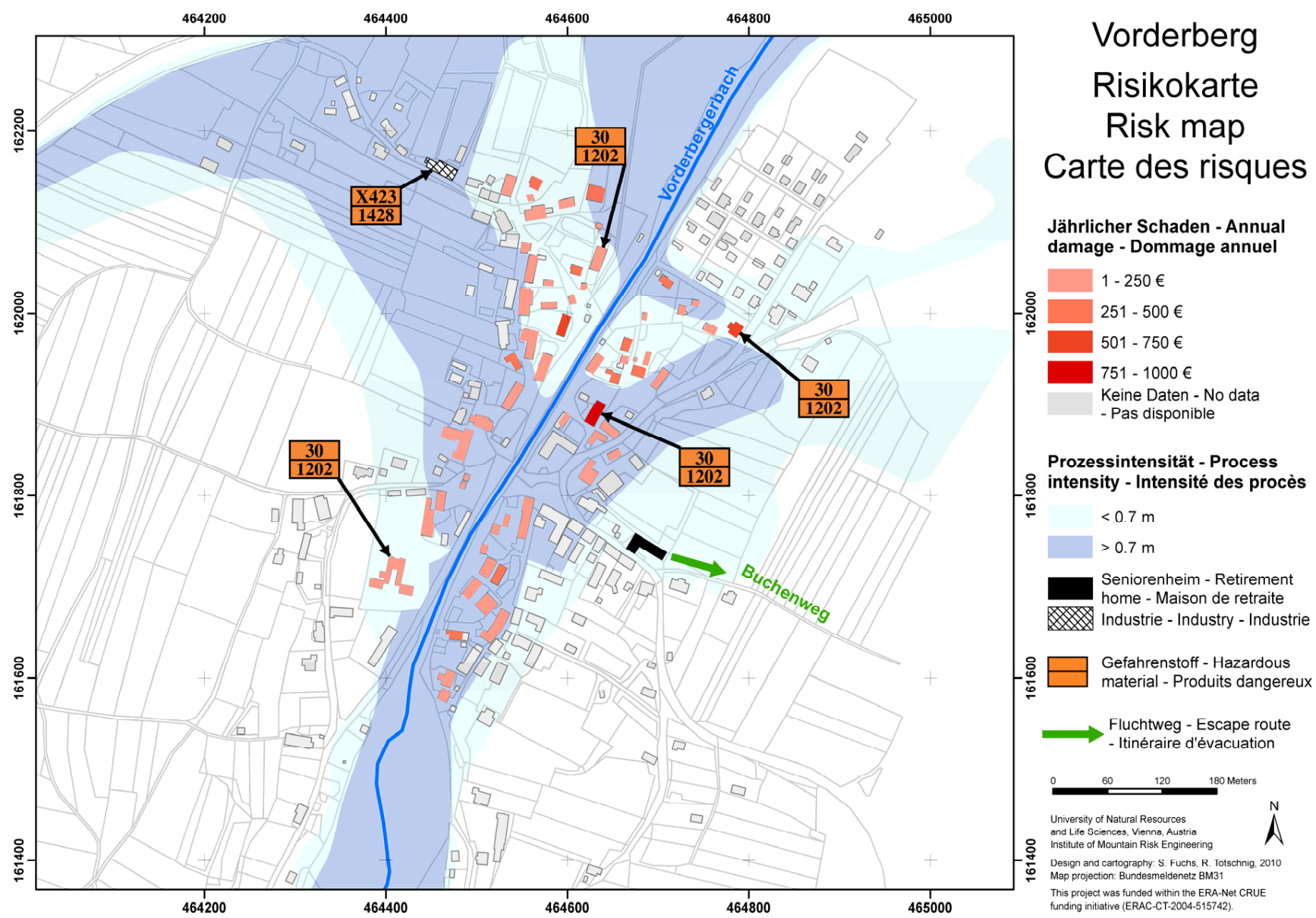

Fig. 4. Map from the Austrian case study: This map was evaluated very well by test persons in the eye-tracking tests and the associated survey in terms of visualisation. Especially the symbols (hazardous material, evacuation route) attracted the eyes of test persons and were found useful by them.

- Specific icons or symbols can be used to highlight different elements (e.g. major risks, the direction of evacuation routes or the direction of the water flows). Ideally, such icons or symbols should be self-explanatory. This can facilitate map reading, especially for users not familiar with the site (see e.g. Fig. 4)

- Text within the maps can enhance and speed up the transmission of important information. For example, 


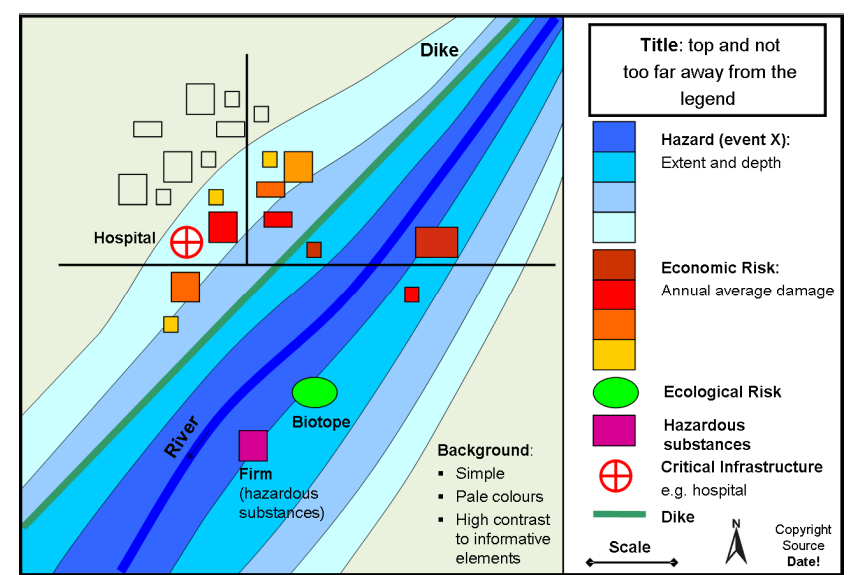

Fig. 5. Idealised map for strategic planning (based on and adjusted from Fuchs et al., 2009.)

information on the number of people to be evacuated in a certain district can be transmitted more easily by text than by symbols of different size or colour gradients.

- The topics in the legend should be organized in a way that it really aids comprehension: firstly hazard information, secondly major risks, then other risks and finally background information. For hazard maps a gradient of blues should be used, and for risk maps a gradient of red.

- Multiple topics dedicated to different user groups should not be shown on the same map. For instance, evacuation information (which is necessary for emergency managers) should not be mixed with information on economic impacts (which is more relevant for strategic planning).

\subsection{Recommendations on the visualisation of flood maps for strategic planning}

Flood risk management actors from strategic planning are usually very familiar with flood maps and - at least in normal decision situations - have enough time to study them in detail; therefore, they are able to deal also with more complex visualization of maps. This means that (cf. Serrhini and Palka, 2011)

- in comparison to flood maps for the other user groups, legends with a relatively high number of classes (4-5) can be used.

- results from the cognitive surveys showed that people from strategic planning like to have information on flood hazard and consequences in the same map.

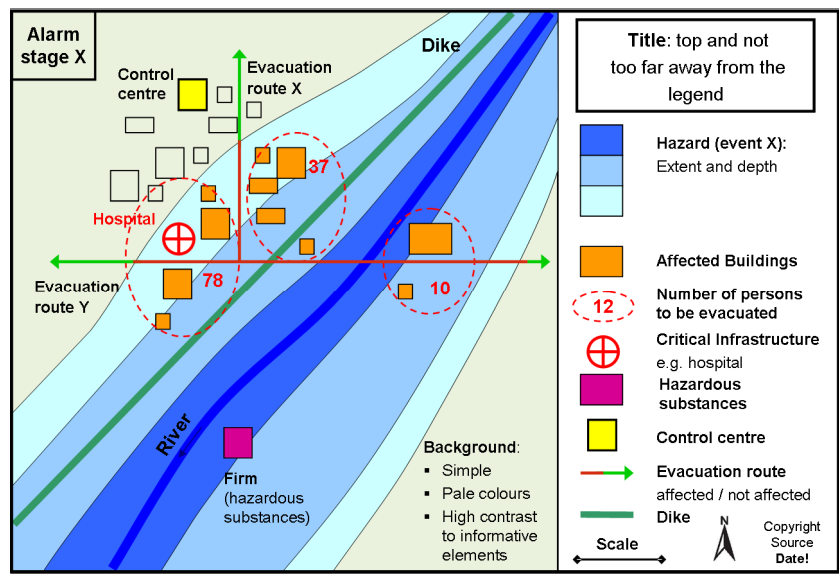

Fig. 6. Idealised map for emergency management (based on and adjusted from Fuchs et al., 2009).

According to these recommendations on visualisation and the recommendations on contents given in Sect. 5, a typical map for strategic planning is presented in Fig. 5.

\subsection{Recommendations on the visualisation of flood maps for emergency management}

In the case of emergency, there is often little time available to read maps. Therefore, the visualization should be kept simple and easy to access. According to findings from the eyetracking tests, surveys and workshops, the following specific recommendations on the visualisation can be given (cf. Serrhini and Palka, 2011; Meyer et al., 2011):

- Classifications in the legends should have a maximum of no more than 3 classes.

- Self-explanatory symbols and text within the map are good ways to visualize the most important information. This is particularly important when there is little time for reading maps so that users do not have to keep referring to the legend for clarification.

- Information on flood hazard and consequences should be shown in the same map.

According to these recommendations on visualisation and the recommendations on contents given in Sect. 5, an example of an idealised map for emergency management is presented in Fig. 6.

\subsection{Recommendations on the visualisation of flood maps for the public}

The visualisation of maps for the public should also be kept as simple as possible, as it cannot be expected that every member of this group is very familiar with map reading. Based on the results from the eye-tracking tests, surveys and 
workshops, the following specific recommendations on the visualisation of maps can be given (cf. Serrhini and Palka, 2011; Meyer et al., 2011):

- Classifications in the legends should have a maximum of no more than 3 classes. Self-explanatory symbols and text within the map are also good ways to visualize the most important information. This is especially important when there is limited time for map reading, as users would not even have to fully recognize the legend to receive the crucial information.

- However, compared to maps for emergency management, the complexity and density of information should be reduced and only the most important contents (the flood extent, the depth, affected buildings and evacuation routes) should be shown and visualized in the maps (see Sect. 5).

According to these recommendations on visualisation and the recommendations on contents given in Sect. 4, an idealised map for the general public is presented in Fig. 7.

\section{Discussion and conclusion}

Having presented these idealised maps, it is important to state that there is of course not only one single ideal map, even for each user group. As outlined in Sect. 2, the recommendations presented in this paper are based on five European case studies, and therefore the findings provide at least an impression of the common needs of map users in different regions, but are of course not representative in a quantitative sense. It has also been shown in the different case studies that regional preferences with regard to map contents and visualisation can be very different. This is in part due to the specific hazard characteristics and exposure of an area and also due to different habits or traditions in map design, for example, the standardised map symbologies used for emergency management. In this sense, the idealised maps (as shown in Sect. 6) should not be seen as a recommendation for standardising flood maps but instead as a basis for further adjustment and tailoring.

Furthermore, as the recommendations for map contents in Sect. 5 suggest, not all map contents can be shown in one map. For example, map users often want event-specific damages displayed on the maps. Therefore, maps for different events need to be produced. The easiest way to allow endusers to receive the maps they require would be to provide them on a digital map server. By selecting map layers according to their needs, individual maps tailored to user requirements can be viewed. However, the existence of such map servers does not guarantee that some users (e.g. the public) recognise or understand the maps or ensure that such maps are available in case of emergency. This means that userspecific print-out versions should be produced for the most important user groups.

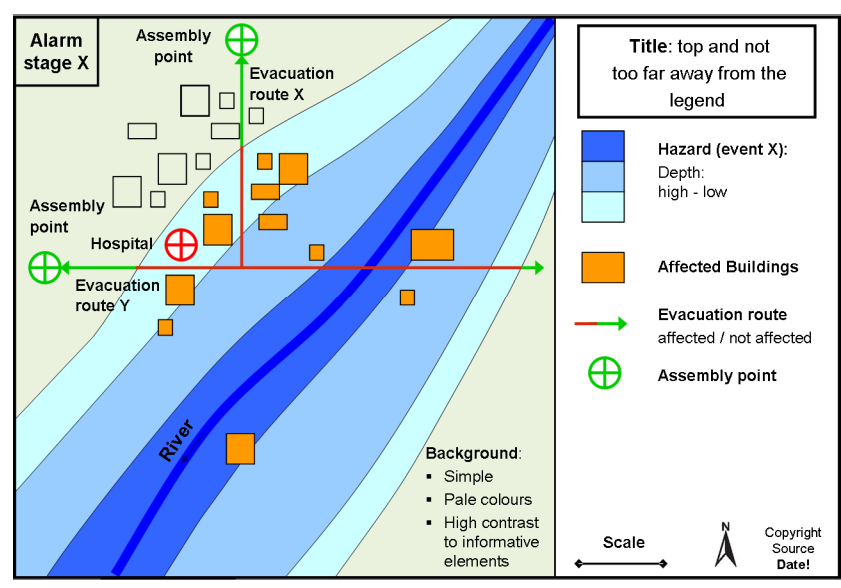

Fig. 7. Idealised map for the general public (based on and adjusted from Fuchs et al., 2009).

A topic that was not discussed in detail in the RISK MAP project was the issue of uncertainty. Flood hazard and risk modellers and map producers are aware that the results of their models are often still to some degree uncertain (cf. Handmer, 2003, Downto and Pielke, 2005, Meyer et al., 2011, Saint-Geours et al., 2011). However, such uncertainties, e.g. in flood extent, are mostly not displayed in the maps, suggesting a non-existing precision to the user. It would be a subject to further research to find ways to visualise such uncertainties in a way that can be easily understood by the users.

Also in this respect, participatory processes (as described in Sect. 4) are an important means to adjust maps so that they are tailored to regional and end-user specific preferences. The research found that such tailoring via participation helps to overcome common barriers to effective risk communication. In addition, participation can be useful, to identify the relevant number of maps to be produced but also to discuss the limitations of maps so that end-users understand how to interpret and respond to mapped information. Experiences from the case studies (as described in Sect. 2) demonstrate that, while time and resource intensive, participation in mapping is worth undertaking to enhance the contents and visualisation of maps in a way that meets end-user needs, thus fundamentally improving the use of maps. The process of transferring the flood hazard and risk maps (as specified by Article 6 of the European FD to the risk management plans (Article 7 FD)) would be a good opportunity for member states to undertake such participation, as the Floods Directive requires an "active involvement of interested parties in the production, review and updating of the risk management plans" (Article 10 FD). Without much further effort required, this participatory process could be also be used to adjust, enhance and improve flood maps. 
Acknowledgements. The work described in this publication was supported by the Era-Net CRUE project RISK MAP, funded by the German Ministry for Education and Research (BMBF), the Austrian Federal Ministry for Agriculture, Forestry, Environment and Water Management (Lebensministerium.at), the UK Department for Environment, Food and Rural Affairs (Defra,) and Environment Agency (EA) and the French Ministry for Ecology, Sustainable Development, Transport and Housing (MEDDTL). This paper reflects the authors' views and not those of the funding bodies mentioned above. The funding bodies are not liable for any use of the information in this paper.

Edited by: S. Longfield

Reviewed by: two anonymous referees

\section{References}

Arbter, K., Handler, M., Purker, E., Tappeiner, G., and Trattnigg, R.: The Public Participation Manual: Shaping the Future Together, Vienna, Austrian Ministry of Environment and ÖGUT 9, 2007.

Barredo, J. I., de Roo, A., and Lavalle, C.: Flood risk mapping at European scale, Water Sci. Technol., 56, 11-17, 2007.

Bell, H. and Tobin, G.: Efficient and effective?, The 100 year flood in the communication and perception of flood risk, Environ. Hazards, 7, 302-311, 2007.

Büchele, B., Kreibich, H., Kron, A., Thieken, A., Ihringer, J., Oberle, P., Merz, B., and Nestmann, F.: Flood-risk mapping: contributions towards an enhanced assessment of extreme events and associated risks, Nat. Hazards Earth Syst. Sci., 6, 485-503, doi:10.5194/nhess-6-485-2006, 2006.

Burningham, K., Fielding, J., and Thrush, D.: It'll never happen to me: understanding public awareness of local flood risk, Disasters, 32, 216-238, 2008.

Collins, H. M. and Evans, R.: The third wave of science studies: studies of expertise and experience, Soc. Stud. Sci., 32, 235-296, 2002.

Cronin, S., Gaylord, D., Charley, D., Alloway, B., Wallerz, S., and Esau, J.: Participatory methods of incorporating scientific with traditional knowledge for volcanic hazard management on Ambae Island, Vanuatu, Bull. Volcanol., 66, 652-668, 2004.

De Bruijn, K. M. and Klijn, F: Risky places in the Netherlands: a first approximation for floods, J. Flood Risk Manage., 2, 258267, 2009.

de Moel, H., van Alphen, J., and Aerts, J. C. J. H.: Flood maps in Europe - methods, availability and use, Nat. Hazards Earth Syst. Sci., 9, 289-301, doi:10.5194/nhess-9-289-2009, 2009.

Downton, M. W. and Pielke, R. A.: How accurate are disaster loss data?, The case of US flood damage, Nat. Hazards, 35, 211-228, 2005.

Ebert, A., Welz, J., Heinrichs, D., Krellenberg, K., and Hansjürgens, B.: Socio-environmental Change and Flood Risks: the Case of Santiago de Chile, Erdkunde, 64, 303-313, 2010.

European Commission: Communication from the Commission to the Council, the European Parliament, the European Economic and Social Committee and the Committee of the Regions, Flood Risk Management: Flood Prevention, Protection and Mitigation, European Commission, Brussels, 2004.

European Commission (Ed.): Risk Assessment and Mapping Guidelines for Disaster Management, Commission Staff Work- ing Paper, Brussels, SEC(2010) 1626 final, 2010.

European Exchange Circle on Flood Mapping (EXCIMAP): Handbook on Good Practices for Flood Mapping in Europe, EXCIMAP, available at: http://caphaz-net.org/outcomes-results (last access: 9 May 2012), 2007.

European Parliament and the Council (Ed.): Directive 2007/60/EC of the European Parliament and of the Council of 23 October 2007 on the assessment and management of flood risks, Vol. L288 of the Official Journal of the European Union, 2007.

Fiorino, D.: Environmental risk and democratic process: A critical review, Columbia Journal of Environmental Law, 14, 501-547, 1989.

Fuchs, S., Thöni, M., McAlpin, M. C., Gruber, U., and Bründl, M.: Avalanche hazard mitigation strategies assessed by cost effectiveness analysis and cost benefit analysis - Evidence from Davos, Switzerland, Nat. Hazards, 41, 113-129, 2007.

Fuchs, S., Spachinger, K., Dorner, W., Rochman, J., and Serrhini, K.: Evaluating cartographic design in flood risk mapping, Environ. Hazards, 8, 52-70, 2009.

Hagemeier-Klose, M. and Wagner, K.: Evaluation of flood hazard maps in print and web mapping services as information tools in flood risk communication, Nat. Hazards Earth Syst. Sci., 9, 563574, doi:10.5194/nhess-9-563-2009, 2009.

Handmer, J.: The chimera of precision: Inherent uncertainties in disaster loss assessment, The Australian Journal of Emergency Management, 18, 88-97, 2003.

Haynes, K., Barclay, J., and Pidgeon, N.: Volcanic hazard communication using maps: an evaluation of their effectiveness, Bull. Volcanol., 70, 123-138, 2007.

Heinimann, H.: Naturgefahren aus forstlicher Sicht - Vergangenheit, Gegenwart, Zukunft, Schweizerische Zeitschrift für Forstwesen, 146, 675-686, 1995.

Heinimann, H.: Der Umgang mit Naturrisiken aus ingenieurwissenschaftlicher Sicht, Schweizerische Zeitschrift für Forstwesen, 149, 691-705, 1998.

Höppner, C., Bründl, M., and Buchecker, M.; Risk communication and natural hazards. CapHaz-Net WP5 Report, Swiss Federal Research Institute, WSL, available at: http://caphaz-net.org/ outcomes-results/CapHaz-Net_WP5_Risk-Communication2.pdf (last access: 9 May 2012), 2010.

Hollenstein, K.: Analyse, Bewertung und Management von Naturrisiken, Zürich, Hochschulverlag an der ETH Zürich, 1997.

Holub, M. and Fuchs, S.: Mitigating mountain hazards in Austria - legislation, risk transfer, and awareness building, Nat. Hazards Earth Syst. Sci., 9, 523-537, doi:10.5194/nhess-9-5232009, 2009.

Kenyon, W., Hanley, N., and Nevin, C.: Citizens' juries: an aid to environmental valuation?, Environ. Plan. C, 19, 557-566, 2001.

Kienberger, S., Lang, S., and Zeil, P.: Spatial vulnerability units expert-based spatial modelling of socio-economic vulnerability in the Salzach catchment, Austria, Nat. Hazards Earth Syst. Sci., 9, 767-778, doi:10.5194/nhess-9-767-2009, 2009.

Kienholz, H. and Krummenacher, B.: Symbolbaukasten zur Kartierung der Phänomene, Bern, BfW and BUWAL, 1995.

Kuhlicke, C. and Steinführer, A. (Eds.): Knowledge Inventory State of the art of natural hazards research in the social sciences and further research needs for social capacity building: Leipzig, Germany, available at: http://caphaz-net.org/outcomes-results (last access: 9 May 2012), 2010. 
LAWA - Bund/Länderarbeitsgemeinschaft Wasser (German Working Group on water issues of the Federal States and the Federal Government represented by the Federal Environment Ministry): Recommendations for the Establishment of Flood Hazard Maps and Flood Risk Maps, Dresden, available at: http://www.lawa.de/ Publications.html (last access: 9 May 2012), 2010.

Leone, F. and Lesales, T.: The interest of cartography for a better perception and management of volcanic risk: from scientific to social representations, the case of Mt. Pelée volcano, Martinique (Lesser Antilles), J. Volcanol. Geoth. Res., 186, 186-194, 2009.

Merz, B.: Hochwasserrisiken - Grenzen und Möglichkeiten der Risikoabschätzung, E. Schweizerbartsche Verlagsbuchhandlung (Näglele u. Obermiller), Stuttgart, 2006.

Merz, B., Thieken, A. H., and Gocht. M.: Flood risk mapping at the local scale: Concepts and challenges, in: Flood Risk Management in Europe: Innovation in Policy and Practice, edited by: Begum, S., Stive, M. J. F., and Hall, J. W., Series: Advances in Natural and Technological Hazards Research, Springer, Dordrecht, Vol. 25, Chapter 13, 231-251, 2007.

Meyer, V., Haase, D., and Scheuer, S.: Flood Risk Assessment in European River Basins - Concept, Methods and Challenges, exemplified at the Mulde River, Integrated Environmental Assessment and Management, 5, 17-26, 2009.

Meyer, V., Kuhlicke, C., Luther, J., Unnerstall, H., Fuchs, S., Priest, S., Pardoe, J., McCarthy, S., Dorner, W., Seidel, J., Serrhini, K., and Palka, G.: RISK MAP - Improving Flood Risk Maps as a Means to Foster Public Participation and Raising Flood Risk Awareness: Toward Flood Resilient Communities. Final Project Report, available at: http://risk-map.org/outcomes (last access: 9 May 2012), 2011.

Meyer, V., Becker, N., Markantonis, V., Schwarze, R., Aerts, J., van den Bergh, J., Bouwer, L., Bubeck, P., Ciavola, P., Daniel, V., Genovese, E., Green, C., Hallegatte, S., Kreibich, H., Lequeux, Q., Lochner, B., Logar, I., Papyrakis, E., Pfurtscheller, C., Poussin, J., Przyluski, V., Thieken, A., Thompson, P., and Viavattene, C.: Costs of Natural Hazards - A Synthesis, available at: http://conhaz.org/outcomes-1 (last access: 9 May 2012), 2012.

Priest, S. J., Pardoe, J., and McCarthy, S.: Theory and methods of participation, in: RISK MAP - Improving Flood Risk Maps as a Means to Foster Public Participation and Raising Flood Risk Awareness: Toward Flood Resilient Communities, edited by: Meyer, V., Kuhlicke, C., Luther, J., Unnerstall, H., Fuchs, S., Priest, S., Pardoe, J., McCarthy, S., Dorner, W., Seidel, J., Serrhini, K., and Palka, G., available at: http://risk-map.org/ outcomes (last access: 9 May 2012), 2011.

Priest, S. J., Pardoe, J., McCarthy, S., and Viavattene, C.: Narrowing the focus: Public understanding of flood maps in the River Thames catchment, Proceedings of Urban Flood Risk Management: Approaches to enhance resilience of communities International Symposium, Graz, Austria, 21-23 September 2011, 309314, $2011 \mathrm{~b}$.
Rowe, G. and Frewer, L.: Public Participation Methods: A Framework for Evaluation, Sci. Technol. Hum. Val., 25, 3-29, 2000.

Saint-Geours, N., Lavergne C., Bailly, J.-S., and Grelot, F.: Analyse de sensibilité globale d'un modèle spatialisé pour l'évaluation économique du risque d'inondation, Journal de la Société Française de Statistique, 152, 49-71, 2011.

Scheuer, S., Haase, D., Meyer, V., Luther, J., and Kuhlicke, C.: Enhancing Flood Risk Assessment, Management and Mapping by means of a Risk Assessment Ontology. Proceedings of Urban Flood Risk Management: Approaches to enhance resilience of communities International Symposium, Graz, Austria, 2123 September 2011, 2011.

Seidel, J. and Dorner, W.: Current practices of flood mapping in the case studies, in: RISK MAP - Improving Flood Risk Maps as a Means to Foster Public Participation and Raising Flood Risk Awareness: Toward Flood Resilient Communities, edited by: Meyer, V., Kuhlicke, C., Luther, J., Unnerstall, H., Fuchs, S., Priest, S., Pardoe, J., McCarthy, S., Dorner, W., Seidel, J., Serrhini, K., and Palka, G., available at: http://risk-map.org/ outcomes (last access: 9 May 2012), 2011.

Seidel, J. and Dorner, W.: Flood Risk Maps for Disaster Control. Application and Resulting Requirements, Proceedings of Urban Flood Risk Management: Approaches to enhance resilience of communities International Symposium, Graz, Austria, 21-23 September 2011, 2011b.

Serrhini, K. and Palka, G.: Appendix C: Detailed Report on Experimental Graphic Semiology, available at: http://risk-map.org/ outcomes/ (last access: 9 May 2012), 2011.

Steinführer, A., Kuhlicke, C., De Marchi, B., Scolobig, A., Tapsell, S., and Tunstall, S.: Towards flood risk management with the people at risk: from scientific analysis to practice recommendations (and back), in: Flood Risk Management: Research and Practice, edited by: Samuels, P., Huntington, S., Allsop, W., and Harrop, J., CRC Press/Balkema, Leiden, 945-955, 2008.

Stirling, A.: Analysis, participation and power: justification and closure in participatory multi-criteria analysis, Land Use Policy, 23, 95-107, 2006.

Unnerstall, H.: Legal Framework for Public Participation in Flood Risk Mapping - A comparative study on different European member states and on the requirements of the Flood Management Directive, UFZ Discussion Paper 13/2010, Leipzig, 2010.

Unnerstall, H.: Legal Framework for Public Participation in Flood Risk Mapping, Proceedings of Urban Flood Risk Management: Approaches to enhance resilience of communities International Symposium, Graz, Austria, 21-23 September 2011, 2011.

Zeisler, P.: Hochwassergefahrenkarten aus Sicht der Praxis, Wasserwirtschaft, 11, 33-36, 2010. 